\title{
Partisipasi Masyarakat dalam Program Nasional Pemberdayaan Masyarakat-Mandiri Di Desa Kotabatu, Kecamatan Ciomas, Kabupaten Bogor
}

\section{Community Participation in Program Nasional Pemberdayaan Masyarakat-Mandiri in Kotabatu Village, Ciomas Sub-District, Bogor District}

\author{
Nurul Fitriyanti ${ }^{1}$, Dwi Sadono ${ }^{1}$ \\ ${ }^{1}$ Departemen Sains Komunikasi dan Pengembangan Masyarakat, \\ Fakultas Ekologi Manusia, FEMA - IPB
}

\begin{abstract}
This research focuses on community participation in the Program Nasional Pemberdayaan Masyarakat-Mandiri in Kotabatu Rural, District Ciomas, Bogor Regency. This study uses quantitative with survey methods and qualitative methods with in-depth interviews. Respondents in this study amounted to 45 people and are selected by random sampling method. The purposes of this study are 1) to analyze the correlation of internal factors in the community with the level of participation in PNPM-Mandiri, 2) to analyze the correlation of external factors that exist in the community with the level of participation in PNPM-Mandiri, and 3) to analyze the correlation between community participation the level of achievement gained in the community-PNPM Mandiri program. Based on the research results to internal factors that influence is age and external factors that influence is intensity of communication. In this program, people participate less, but people still feel a high level of achievement.
\end{abstract}

Keywords: Participation, internal factors, external factors, and achievement.

\begin{abstract}
Abstrak
Penelitian ini berfokus pada partisipasi masyarakat dalam Program Nasional Pemberdayaan Masyarakat-Mandiri di Desa Kotabatu, Kecamatan Ciomas, Kabupaten Bogor. Penelitian ini menggunakan metode kuantitatif dengan metode survey dan metode kualitatif dengan wawancara mendalam. Responden dalam penelitian ini berjumlah 45 orang dan dipilih dengan metode sampel acak. Tujuan dari penelitian ini adalah 1) Menganalis hubungan faktor internal yang ada di masyarakat dengan tingkat partisipasi dalam program PNPM-Mandiri, 2) Menganalisis hubungan faktor eksternal yang ada di masyarakat dengan tingkat partisipasi dalam program PNPM-Mandiri, dan 3) Menganalisis hubungan tingkat partisipasi masyarakat dengan tingkat pencapaian yang diperoleh masyarakat dalam program PNPM-Mandiri. Berdasarkan hasil penelitian diperoleh hasil faktor internal yang berpengaruh adalah usia dan faktor eksternal yang sangat berpengaruh adalah intensitas komunikasi. Pada program ini masyarakat kurang berpartisipasi tetapi masyarakat tetap merasakan tingkat pencapaian yang tinggi.
\end{abstract}

Kata kunci: Partisipasi, faktor internal, faktor eksternal, dan pencapaian

\section{Pendahuluan}

Pembangunan di wilayah pedesaan tentunya tidak akan terlepas dari pelibatan masyarakat dan stakeholders yang terlibat. Pentingnya pelibatan masyarakat dalam sebuah proses pembangunan di pedesaan dapat menjadi faktor keberhasilan program tersebut. Partisipasi adalah proses aktif inisiatif diambil oleh warga komunitas sendiri, dibimbing oleh cara berfikir mereka sendiri, dengan menggunakan sarana dan proses dimana mereka dapat menegaskan kontrol secara efektif. Partisipasi tersebut dapat dikategorikan: pertama, warga komunitas dilibatkan dalam tindakan yang telah dipikirkan atau dirancang oleh orang lain dan dikontrol oleh orang lain. Kedua, partisipasi merupakan proses pembentukan kekuatan untuk keluar dari masalah mereka sendiri. Titik tolak partisipasi adalah memutuskan, bertindak, kemudian mereka merefleksikan tindakan tersebut pada subjek yang sadar (Nasdian, 2012).

Tujuan PNPM adalah untuk meningkatkan kesejahteraan dan kesempatan kerja masyarakat miskin secara mandiri, meningkatkan partisipasi seluruh masyarakat, termasuk masyarakat miskin, komunitas adat terpencil dan kelompok masyarakat lainnya yang rentan dan sering terpinggirkan ke dalam proses pengambilan keputusan dan pengelolaan pembangunan. Meningkatkan kapasitas kelembagaan dan pemerintah dalam bersinergi dengan masyarakat untuk mengefektifkan program-program pembangunan pedesaan yang sesuai dengan kearifan lokal yang terdapat pada daerah tersebut. Program pemberdayaan masyarakat ini dapat dikatakan sebagai program pemberdayaan masyarakat terbesar di tanah

${ }^{1}$ Korespondensi penulis 
air, bahkan terbesar di dunia. Pelaksanaan program ini memprioritaskan kegiatan bidang infrastruktur desa, pengelolaan pinjaman bergulir bagi kelompok swadaya masyarakat, kegiatan pendidikan dan kesehatan bagi masyarakat di wilayah pedesaan. Ruang lingkup PNPM-Mandiri ialah seluruh anggota masyarakat yang didorong untuk terlibat dalam setiap tahapan kegiatan secara partisipatif, mulai dari proses perencanaan, pengambilan keputusan dalam upaya penggunaan dan pengelolaan dana sesuai kebutuhan paling prioritas di desanya, sampai pada pelaksanaan kegiatan dan pelestariannya (Program Nasional Pemberdayaan Masyarakat, 2013).

DesaKotaBatuKecamatanCiomas Kabupaten Bogor, menjadi salah satu lokasi sasaran kegiatan pelaksanaan PNPM-Mandiri sejak tahun 2010. Program Pinjaman Bergulir di Desa Kotabatu yang dapat memberikan manfaat jangka pendek maupun jangka panjang secara ekonomi bagi masyarakat miskin atau rumah tangga miskin serta sasaran dari kegiatan tersebut. Program Pinjaman Bergulir adalah salah satu bentuk program pemberdayaan ekonomi dari beberapa program dari PNPM-Mandiri yang ada di Desa Kotabatu. Pelaksanaan kegiatan pinjaman bergulir bertujuan untuk menyediakan akses layanan keuangan kepada rumah tangga miskin dengan pinjaman mikro berbasis pasar dengan kegiatan yang menghasilkan pendapatan yang biasanya tidak memiliki akses ke sumber pinjaman yang lainnya, untuk memperbaiki kondisi ekonomi mereka dan kegiatan yang mendukung tumbuhnya ekonomi serta usaha mikro disamping itu membelajarkan mereka dalam hal mengelola pinjaman dan menggunakannya secara benar.

Program Pinjaman Bergulir tersebut sudah berjalan sejak tahun 2010 sampai sekarang. Salah satu prinsip dasar PNPM-Mandiri adalah partisipasi. Pengertian prinsip partisipasi adalah masyarakat berperan secara aktif dalam proses atau alur tahapan program dan pengawasannya, mulai dari tahap sosialisasi, perencanaan, pelaksanaan dan pelestarian kegiatan.Secara umum, PNPM-Mandiri merupakan program yang memiliki prinsip bottom up, dimana kegiatan tersebut bertumpu pada masyarakat dan membutuhkan partisipasi masyarakat. Oleh karena itu, menjadi penting untuk dilihat bagaimana partisipasi warga masyarakat (pelibatan dari tahap pengambilan keputusan hingga tahap evaluasi) dalam sebuah program besar pemerintah yaitu PNPM-Mandiri?
Faktor-faktor yang dapat menjadi penghambat pemberdayaan dan partisipasi serta menjadi penyebab permasalahan masyarakat lapisan bawah di tingkat komunitas tidak berdaya menghadapi lapisan yang lebih kuat perlu dicermati dan diperhatikan dengan baik. Salah satunya adalah faktor internal. Faktor internal berasal dari dalam diri atau karakteristik individu yang mempengaruhi pemberdayaan dan partisipasi di tingkat komunitas. Faktor internal yang berhubungan yaitu usia, tingkat pendidikan, jenis pekerjaan dan tingkat pendapatan. Faktor eksternal adalah faktor-faktor yang menghambat pemberdayaan dan partisipasi serta menjadi penyebab permasalahan masyarakatditingkatkomunitasmenjaditidakberdaya. Faktor eksternal yang berhubungan yaitu keaktifan pemimpin formal/informal, intensitas komunikasi, intensitas sosialisasi kegiatan dan keaktifan fasilitator. Hasil sebuah program pemberdayaan dapat dinilai oleh keberhasilan program yang dilaksanakan secara partisipasi. Keberhasilan suatu program pembangunan akan sangat efektif dan efisien jika dapat dinikmati atau dimanfaatkan secara bersama-sama oleh seluruh lapisan masyarakat. Tingkat pencapaian yang diperoleh yaitu peningkatan fasilitas sarana sosial dan ekonomi, peningkatan peluang usaha, peningkatan partisipasi masyarakat dalam kegiatan ekonomi pedesaan, peningkatan pendapatan rumah tangga dan peningkatan kemandirian warga dalam menunjang kebutuhan hidup. Sehubungan dengan itu, untuk memperoleh gambaran komprehensif mengenai partisipasi masyarakat dalam Program Nasional Pemberdayaan Masyarakat-Mandiri tersebut, maka rumusan permasalahan penelitian yang akan dikaji adalah:

1. Bagaimana hubungan faktor internal yang ada di masyarakat dengan tingkat partisipasi dalam program PNPM-Mandiri?

2. Bagaimana hubungan faktor eksternal yang ada di masyarakat dengan tingkat partisipasi dalam program PNPM-Mandiri?

3. Bagaimana hubungan tingkat partisipasi dengan tingkat pencapaian yang diperoleh masyarakat dalam program PNPM-Mandiri?

Penelitian bertujuan untuk (1) menganalisis hubungan faktor internal yang ada di masyarakat dengan tingkat partisipasi dalam program PNPM-Mandiri (2) menganalisis hubungan faktor eksternal yang ada di 
masyarakat dengan tingkat partisipasi dalam program PNPM-Mandiri (3) menganalisis hubungan tingkat partisipasi masyarakat dengan tingkat pencapaian yang diperoleh masyarakat dalam program PNPM-Mandiri.

\section{Metode Penelitian}

Penelitian ini menggunakan dua pendekatan, kuantitatif dan kualitatif. Penelitian kuantitatif yang dilakukan merupakan penelitian survei. Metode kuantitatif dilakukan melalui pengisian kuesioner dan metode kualitatif dengan menggunakan teknik wawancara mendalam. Penelitian ini dilakukan di Desa Kotabatu Kecamatan Ciomas Kabupaten Bogor. Pemilihan lokasi penelitian dilakukan secara purposive (sengaja). Desa Kotabatu Kecamatan Ciomas Kabupaten Bogor, menjadi salah satu lokasi sasaran kegiatan pelaksanaan Program Pinjaman Bergulir dari PNPM sejak tahun 2010. Tahap peminjaman bergulir yang dilakukan masyarakat sudah berada pada tahap akhir (tahap peminjaman dengan nominal tertinggi) dan tingkat pengembalian sebanyak $80 \%$. Populasi pada penelitian ini adalah seluruh masyarakat Desa Kotabatu. Responden dalam penelitian ini berjumlah 45 orang, dan pemilihan dilakukan secara acak.

Penelitian menggunakan pendekatan kuantitatif dan kualitatif. Penelitian kuantitatif yang dilakukan merupakan penelitian survei. Metode kuantitatif dilakukan melalui pengisian kuesioner dan metode kualitatif dengan menggunakan teknik wawancara mendalam. Penelitian ini dilakukan di Desa Kotabatu Kecamatan Ciomas Kabupaten Bogor. Pemilihan lokasi penelitian dilakukan secara purposive(sengaja). Desa Kotabatu Kecamatan Ciomas Kabupaten Bogor, menjadi salah satu lokasi sasaran kegiatan pelaksanaan Program Pinjaman Bergulir dari PNPM sejak tahun 2010. Tahap peminjaman bergulir yang dilakukan masyarakat sudah berada pada tahap akhir (tahap peminjaman dengan nominal tertinggi) dan tingkat pengembalian sebanyak $80 \%$. Populasipada penelitian ini adalah seluruh masyarakat Desa Kotabatu. Responden dalam penelitian ini berjumlah 45 orang, dan pemilihan dilakukan secara acak. Data diuji dengan menggunakan Rank Spearman.

\section{Hasil dan Pembahasan}

Desa Kotabatu terletak di wilayah Kecamatan Ciomas, Kabupaten Bogor, Jawa Barat. Desa ini mempunyai luas wilayah \pm 274 ha. Secara geografis, Desa Kotabatu dibatasi oleh Kelurahan Cikaret/ Mekarjaya di sebelah utara, Desa Suka Mantri dan Sirna di sebelah selatan, Kelurahan Cikaret di sebelah timur dan Desa Parakan dan Desa Sirna di sebelah baratnya. Desa Kotabatu berada di bawah kaki Gunung Salak dengan struktur masyarakat yang sudah urban. Hal ini dapat dilihat dari luas pemukiman yang lebih luas dibandingkan dengan luas persawahan maupun perkebunan. Desa Kotabatu berada tidak jauh dari Kota Bogor, dengan menggunakan angkutan kota 03 Ciapus dari pintu utama Kebun Raya Bogor, Desa Kotabatu dapat ditempuh dengan 45 menit. Banyaknya angkutan kota yang melintas membuat mobilisas di Desa Kotabatu sangat ramai.

Sebagian besar penduduk Desa Kotabatu bermata pencaharian sebagai karyawan perusahaan swasta. Berdasarkan data potensi Desa Kotabatu jumlah kepala keluarga yaitu 4.925 KK. Penduduk di Desa Kotabatu komposisi terbesar berpendidikan SD yaitu dengan jumlah 4.157 orang (2.081 orang laki-laki dan 2.076 orang perempuan).

\section{Hubungan Faktor Internal dengan Tingkat Partisipasi}

\section{Faktor Internal}

Faktor internal dalam penelitian ini merupakan karakteristik responden yang terdiri dari usia, tingkat pendidikan, jenis pekerjaan dan tingkat pendapatan responden pada Program Pinjaman Bergulir Desa Kotabatu, Kecamatan Ciomas, Kabupaten Bogor. Data dapat dilihat pada Tabel 1 Sebaran jumlah dan persentase responden menurut faktor internal dalam Program Pinjaman Bergulir di Desa Kotabatu.

\section{Tingkat Partisipasi}

Penelitian ini melihat tingkat partisipasi masyarakat dari keaktifan masyarakat tersebut dalam mengikuti kegiatan Program Pinjaman Bergulir dari tahap pengambilan keputusan, tahap pelaksanaan, tahap menikmati hasil dan tahap evaluasi di Desa Kotabatu, Kecamatan Ciomas,

\section{Hubungan Usia dengan Tingkat Partisipasi}

Responden yang berusia 20 sampai 40 
Tabel 1 Sebaran jumlah dan Persentase Responden menurut Faktor Internal dalam Program Pinjaman Bergulir di Desa Kotabatu

\begin{tabular}{|c|c|c|c|}
\hline \multicolumn{2}{|c|}{ Karakteristik individu $(n=45)$} & \multirow{2}{*}{$\frac{\text { Jumlah (orang) }}{20}$} & \multirow{2}{*}{$\begin{array}{c}\text { Persentase (\%) } \\
44,44\end{array}$} \\
\hline usia & - 20 sampai 40 tahun & & \\
\hline & - $\quad 41$ sampai $>80$ tahun & 25 & 55,56 \\
\hline \multirow[t]{4}{*}{ Tingkat pendidikan } & - Tidak sekolah & 3 & 6,67 \\
\hline & - $\quad \mathrm{SD}$ & 22 & 48,89 \\
\hline & - $\quad$ SMP & 12 & 26,67 \\
\hline & - $\quad$ SMA/SMK & 8 & 17,77 \\
\hline \multirow[t]{4}{*}{ Jenis pekerjaan } & - Tidak bekerja & 0 & 0,00 \\
\hline & - Ibu rumahtangga & 43 & 95,56 \\
\hline & - Buruh/pedagang & 2 & 4,44 \\
\hline & - Karyawan swasta & 0 & 0,00 \\
\hline \multirow[t]{2}{*}{ Tingkat pendapatan } & - $\quad<\mathrm{Rp} 2.042 .000$ & 32 & 71,11 \\
\hline & - $\quad>\operatorname{Rp} 2.042 .000$ & 13 & 28,89 \\
\hline
\end{tabular}

tahun memiliki tingkat partisipasi yang tinggi, sementara responden yang berusia 41 sampai $>80$ tahun memiliki tingkat partisipasi yang rendah. Hasil uji statistik dengan menggunakan uji RankSpearman menunjukan hasil nilai signifikansi sebesar 0,023. Penelitian ini membuktikan bahwa terdapat hubungan nyata antara usia dengan tingkat partisipasi masyarakat. Responden yang berusia 20 sampai 40 tahun lebih berpartisipasi dan dipercaya sebagai ketua kelompok, sementara responden yang berusia 41 sampai $>80$ tahun hanya menerima informasi dari ketua kelompok saja.

\section{Hubungan Tingkat Pendidikan dengan Tingkat Partisipasi}

Sebagian besar responden yang tidak sekolah memiliki tingkat Partisipasi yang rendah, responden yang berpendidikan SD memiliki tingkat partisipasi yang cenderung tinggi, responden yang berpendidikan SMP sebagian besar memiliki tingkat partisipasi yang rendah dan responden yang berpendidikan SMA/ SMK memiliki tingkat partisipasi tinggi. Hasil uji statistik dengan menggunakan uji Rank Spearman menunjukan hasil nilai signifikansi sebesar 0,897 . Penelitian ini membuktikan bahwa tidak terdapat hubungan nyata antara tingkat pendidikan dengan tingkat partisipasi masyarakat. Partisipasi masyarakat Desa Kotabatu yang memiliki pendidikan sampai Sekolah Dasar memiliki tingkat partisipasi yang tinggi karena mereka perlu untuk memahami dan melaksanakan partisipasi dengan baik, agar mereka dapat diberikan kepercayaan oleh tim pendamping dalam Program Pinjaman Bergulir dan tidak memiliki kendala yang nantinya dapat menyebabkan sulit pengembalian pinjaman per jatuh tempo.

\section{Hubungan Jenis Pekerjaan dengan Tingkat Partisipasi Masyarakat}

Responden yang memiliki pekerjaan sebagai ibu rumahtangga memiliki tingkat partisipasi sedikit lebih tinggi, sementara responden yang bekerja sebagai buruh atau pedagang memiliki tingkat partisipasi yang relatif seimbang. Hasil uji statistik dengan menggunakan uji Chi Square menunjukan hasil nilai signifikansi sebesar 0,974. Penelitian ini membuktikan bahwa jenis pekerjaan tidak berbeda nyata dengan tingkat partisipasi masyarakat. Masyarakat yang berprofesi sebagai ibu rumahtangga mengikuti Program Pinjaman Bergulir dengan motivasi untuk memenuhi kebutuhan rumahtangga sehari-hari dan membantu suami.

\section{Hubungan Tingkat Pendapatan dengan Tingkat Partisipasi Masyarakat}

Responden yangmemilikipendapatan dibawah Rp 2.042.000 memiliki tingkat partisipasi yang tinggi, sementara responden yang memiliki pendapatan di atas Rp 2.042.000 memiliki tingkat partisipasi rendah. Hasil uji statistik dengan menggunakan uji Rank Spearman menunjukan hasil nilai signifikansi sebesar 0,680 . Penelitian ini membuktikan bahwa tidak terdapat 
Tabel 2 Sebaran Jumlah dan Persentase Responden menurut Faktor Eksternal dalam Program Pinjaman Bergulir di Desa Kotabatu

\begin{tabular}{llll}
\hline \multicolumn{1}{c}{ Faktor Eksternal } & & Jumlah (orang) & Persentase (\%) \\
\hline Keaktifan pemimpin & & 12 & 26,67 \\
& tinggi & 33 & 73,33 \\
Intensitas komunikasi & Rendah & 18 & 40,00 \\
& Tinggi & 27 & 60,00 \\
Intensitas sosialisasi kegiatan & rendah & 14 & 31,11 \\
& Tinggi & 31 & 68,89 \\
Keaktifan fasilitator & rendah & 10 & 22,22 \\
& Tinggi & 35 & 77,78 \\
\hline
\end{tabular}

hubungan nyata antara jenis pekerjaan dengan tingkat partisipasi masyarakat. Hal ini dikarenakan adanya motivasi untuk memperoleh bantuan dari Program Pinjaman Bergulir dan memanfaatkan bantuan tersebut secara efektif dengan menggunakannya sebagai modal usaha, sebagai cara untuk meningkatkan pendapatan dalam memenuhi kebutuhan sehari-hari.

\section{Hubungan Faktor Eksternal dengan Tingkat Partisipasi Masyarakat}

\section{Faktor Eksternal}

Faktor eksternal dalam penelitian ini adalah faktor-faktor yang berasal dari luar diri individu atau lingkungan yang berhubungan seseorang untuk ikut berpartisipasi dalam program PNPM-Mandiri. Faktor eksternal meliputi kepemimpinan formal/informal, intensitas sosialisasi kegiatan pada Program Pinjaman Bergulir di Desa Kotabatu, Kecamatan Ciomas, Kabupaten Bogor. Data dapat dilihat pada Tabel 2 Sebaran jumlah dan persentase respondenmenurut faktor eksternal dalam Program Pinjaman Bergulir di Desa Kotabatu.

\section{Hubungan Keaktifan Pemimpin Formal/ Informal dengan Tingkat Partisipasi Masyarakat}

Pada kategori keaktifan pemimpin yang rendah, tingkat partisipasi masyarakat tergolong rendah. Sebaliknya pada kategori keaktifan pemimpin yang tinggi, tingkat partisipasi masyarakat cenderung tinggi. Uji statistik dilakukan dengan menggunakan Rank Spearman dengan nilai signifikansi yaitu sebesar 0,055. Penelitian ini membuktikan bahwa tidak terdapat hubungan nyata antara keaktifan pemimpin formal/informal dengan tingkat partisipasi masyarakat. Peran pemimpin seperti kepala desa, ketua RW dan ketua RT kurang terlihat di beberapa wilayah Desa Kotabatu.

\section{Hubungan Intensitas Komunikasi dengan Tingkat Partisipasi Masyarakat}

Pada kategori intensitas komunikasi yang rendah, tingkat partisipasi masyarakat tergolong rendah. Sebaliknya pada kategori intensitas komunikasi yang tinggi, tingkat partisipasi masyarakat tergolong tinggi. Uji statistik dilakukan dengan menggunakan Rank Spearman dengan nilai signifikansi yaitu sebesar 0,003 .

Penelitian ini membuktikan bahwa terdapat hubungan nyata antara intensitas komunikasi dengan tingkat partisipasi masyarakat. Semakin efektif komunikasi antara tim pendamping, masyarakat yang efektif pula. Intensitas komunikasi dilakukan oleh tim pendamping yaitu bu WI hanya dilakukan jika ada pemberitahuan informasi tentang pencairan uang, pemberitahuan jatuh tempo pengembalian pinjaman dan pemberitahuan pelatihan-pelatihan yang akan dilaksanakan.

\section{Hubungan Intensitas Sosialisasi Kegiatan dengan Tingkat Partisipasi Masyarakat}

Pada kategori intensitas sosialisasi kegiatan yang rendah, tingkat partisipasi masyarakat tergolong rendah. Sebaliknya pada kategori intensitas sosialisasi kegiatan yang tinggi, tingkat partisipasi masyarakat 
tergolong tinggi. Uji statistik dilakukan dengan menggunakan Rank Spearmandengan nilai signifikansi yaitu sebesar 0,013. Penelitian ini membuktikan bahwa terdapat hubungan nyata antara intensitas sosialiasi kegiatan dengan tingkat partisipasi masyarakat. Hal ini dikarenakan adanya pelatihan-pelatihan yang dilakukan oleh tim pendamping dengan mengacu pada penguatan kelompok swadaya masyarakat agar program ini tetap berjalan dengan stabil.

\section{Hubungan Keaktifan Fasilitator dengan Tingkat Partisipasi Masyarakat}

Pada kategori keaktifan para fasilitator yang rendah, tingkat partisipasi masyarakat cenderung rendah. Sebaliknya pada kategori keaktifan fasilitator yang tinggi, tingkat partisipasi masyarakat tinggi. Uji statistik dilakukan dengan menggunakan Rank Spearman dengan nilai signifikansi yaitu sebesar 0,039 . Penelitian ini membuktikan bahwa terdapat hubungan nyata antara keaktifan fasilitator dengan tingkat partisipasi masyarakat. Hal ini diperkuat oleh fakta di lapang yaitu kebanyakan dari responden tidak mengenal fasilitator, karena mereka jarang mengikuti pelatihan-pelatihan yang diadakan oleh tim pendamping dari PNPM.

\section{Hubungan Tingkat Partisipasi Masyarakat dengan Tingkat Pencapaiannya}

Tingkat pencapaian adalah hasil yang dapat dirasakan manfaatnya oleh masyarakat dari mengikuti Program Pinjaman Bergulir di Desa Kotabatu, Kecamatan Ciomas, Kabupaten Bogor. Penelitian ini melihat bagaimana responden merasakan peningkatan fasilitas sarana sosial, fasilitas sarana ekonomi, peluang usaha untuk masyarakat yang mengikuti Program Pinjaman Bergulir, partisipasi masyarakat dalam kegiatan ekonomi pedesaan setelah mengikuti Program Pinjaman Bergulir, peningkatan pendapatan rumahtangga setelah mengikuti Program Pinjaman Bergulir dan kemandirian warga dalam menunjang kebutuhan hidup masyarakat Desa Kotabatu setelah mengikuti Program Pinjaman Bergulir. Pada kategori tingkat partisipasi yang rendah, masyarakat merasakan tingkat pencapaian yang tinggi dan pada tingkat partisipasi yang tinggi, masyarakat juga merasakan tingkat pencapaian yang tinggi. Uji statistik dilakukan dengan menggunakan Rank Spearman dengan nilai signifikansi yaitu sebesar 0,618.

Berdasarkan hasil tersebut, terlihat bahwa walaupun masyarakat yangmengikutiProgramPinjaman Bergulir berpartisipasi rendah, tetapi mereka tetap merasakan tingkat pencapaian yang tinggi. Masyarakat yang mengikuti Program Pinjaman Bergulir tetap mendapatkan pengetahuan dari pelatihan-pelatihan dalam Program Pinjaman Bergulir, memiliki teman atau relasi yang ada di wilayah RT/RW lainnya setelah mengikuti pelatihan dan memperoleh wawasan untuk meningkatkan motivasi dalam berpartisipasi dari tahap pengambilan keputusan sampai tahap evaluasi.

\section{Kesimpulan}

Tingkat partisipasi masyarakat pada Program Pinjaman Bergulir di Desa Kotabatu cenderung rendah. Tahap pengambilan keputusan, partisipasi masyarakat rendah karena kurangnya keterlibatan masyarakat dalam memberikan masukan, ide dan kritik dalam proses pengambilan keputusan. Tahap pelaksanaan, masyarakat berpartisipasi tinggi karena masyarakat cukup aktif dalam kegiatan Program Pinjaman Bergulir. Tahap menikmati hasil, partisipasi masyarakat tinggi dengan adanya peningkatan pendapatan rumah tangga dan juga meningkatnya peluang usaha setelah mengikuti pelatihan-pelatihan dalam Program Pinjaman Bergulir. Tahap evaluasi, masyarakat kurang berpartisipasi hal ini disebabkan karena rendahnya kesadaran oleh responden dalam mengetahui sejauhmana kelancaran program tersebut.

Karakteristik usia memiliki hubungan nyata dengan tingkat partisipasi. Responden yang berusia lebih muda memiliki tingkat partisipasi yang lebih tinggi dibanding responden yang berusia lebih tua. Responden yang berusia muda lebih berpartisipasi karena mereka lebih aktif untuk mengikuti kegiatankegiatan dan dipercaya untuk menjadi ketua kelompok dan mengurus kelompok. Karakteristik tingkat pendidikan, jenispekerjaan dan tingkat pendapatan tidak memiliki hubungan nyata dengan partisipasi masyarakat. Keaktifan pemimpin formal/ informal belum mampu meningkatkan partisipasi masyarakat. Hal ini karena pemimpin formal/informal kurang terlibat dalam menggerakkan aspirasi masyarakat agar lebih terlibat dalam Program Pinjaman Bergulir. Intensitas komunikasi, intensitas sosialisasi kegiatan dan keaktifan fasilitator memiliki hubungan nyata dengan partisipasi masyarakat. Selain itu, hubungan 
komunikasi, intensitas kegiatan pelatihan yang dilaksanakan dan keaktifan fasilitator yang kuat memiliki hubungan nyata terhadap tingkat partisipasi masyarakat pada Program Pinjaman Bergulir. Faktor eksternal yang berhubungan nyata dengan partisipasi masyarakat dalam Program Pinjaman Bergulir adalah intensitas komunikasi.

Tidak terdapat hubungan antara tingkat partisipasi dengan tingkat pencapaian dalam Program Pinjaman Bergulir di Desa Kotabatu, Kecamatan Ciomas, Kabupaten Bogor. Warga masyarakat tetap merasakan tingkat pencapaian yang tinggi, seperti adanya peningkatan fasilitas sarana sosial dan ekonomi, peningkatan peluang usaha, peningkatan partisipasi masyarakat dalam kegiatan ekonomi pedesaan, peningkatan pendapatan rumahtangga dan peningkatan kemandirian warga dalam menunjang kebutuhan hidup.

\section{Daftar Pustaka}

Achnes S, Mashur D, Sahuri C, Zulkarnaini. 2012. Implementasi PNPM-Mandiri dalam peningkatan kesejahteraan masyarakat. Jurnal Kebijakan Publik. [Internet]. [diunduh tanggal 10 Oktober 2013]. 3 (2): 59-141. Dapat diunduh dari:http://ejournal.unri.ac.id

Azimi S. 2013. Partisipasi stakeholder dalam program tanggungjawab sosial perusahaan dan dampaknya terhadap taraf hidup masyarakat di komunitas Kelurahan Gunung Dempo Sumatera Selatan [skripsi]. Bogor (ID): Departemen Sains Komunikasi dan Pengembangan Masyarakat, Institut Pertanian Bogor.

Badan Pemberdayaan Masyarakat dan Pemerintahan Desa. 2010. Data potensi desa dan kelurahan, Kecamatan Ciomas, Desa Kotabatu. Bogor (ID): (tidak diterbitkan) Kabupaten Bogor.

[BPS] Badan Pusat Statistik. 2012. Perkembangan beberapa indikator utama sosial-ekonomi Indonesia. [Internet]. [diunduh tanggal 2 maret 2014]. 154 hal. Dapat diunduh dari: http://www. bps.go.id/booklet/Booklet_Mei_2012.pdf

[Depdagri] Departemen Dalam Negeri Republik Indonesia. 2008. PTO (PetunjukTeknis Operasional) Program Nasional Pemberdayaan Masyarakat (PNPM)

Mandiri Perdesaan. Jakarta (ID): Tim Koordinasi PNPM Mandiri Perdesaan.
Girsang LJ. 2011. Faktor yang mempengaruhi partisipasi masyarakat dalam kegiatan perbaikan prasarana jalan (Kasus: Program Nasional Pemberdayaan Masyarakat (PNPM)-Mandiri Perdesaan di Desa Megamendung, Bogor) [Skripsi].[Internet]. [diunduh tanggal 10 Oktober 2013]. Dapat diunduh dari: http:// repository.ipb.ac.id

Ife J, Tesoriero F. 2008. Alternatif pengembangan masyarakat di era globalisasi community development. Yogyakarta (ID):Pustaka Pelajar

Indrianingrum L. 2011. Respon masyarakat terhadap metode PNPM P2KP: pengalaman masyarakat Sadang Serang Kota Bandung. Jurnal Teknik Sipil dan kebijakan [Internet]. [diunduh tanggal 30 Oktober 2013]. 13 (1): 61-70. Dapat diunduh dari:-

Mardikanto T. 2010. Konsep-konsep pemberdayaan masyarakat. Surakarta (ID): UNS Press

Nasdian FT. 2012. Pengembangan masyarakat. Bogor (ID): IPB Press

[PNPM]. Program Nasional Pemberdayaan Masyarakat. 2008. Panduan Umum Program Nasional Pemberdayaan Masyarakat (PNPM)Mandiri. Petunjuk teknis operasional PNPMMandiri pedesaan. Jakarta (ID): Departemen Dalam Negeri Republik Indonesia.

[PNPM] Program Nasional Pemberdayaan Masyarakat Mandiri Perkotaan. 2012. Petunjuk teknis pinjaman bergulir. Jakarta(ID): Direktorat Jenderal Cipta Karya, Kementerian Pekerjaan Umum.

[PNPM] Program Nasional Pemberdayaan Masyarakat. 2013. Tentang PNPM-Mandiri Perdesaaan. [diunduh tanggal 10 Oktober 2013]. Dapat diunduh dari: http://www.pnpmperdesaan.or.id

Singarimbun M, Effendi S. 1987. Metode penelitian survai. Jakarta (ID): PT Pustaka LP3ES Indonesia.

Suharto E. 2010. Membangun masyarakat memberdayakan rakyat. Bandung (ID): Refika Aditama.

Sumodiningrat G. 1999. Pemberdayaan masyarakat dan jaringan pengaman sosial. Jakarta (ID): Gramedia Pustaka Utama.

Susantyo B. 2007. Partisipasi masyarakat dalam pembangunan di pedesaaan. [Internet]. [diunduh tanggal 10 Oktober 2013]. 12 (03). Dapat 
Jurnal Penyuluhan, Maret 2013 Vol. 9 No. 1

diunduh di: http://puslit.kemsos.go.id

[UU] Undang-undang Republik Indonesia Nomor 25

Tahun 2004 Program Nasional Pemberdayaan Masyarakat (PNPM)-Mandiri.

Wibowo R. 2011. Pendekatan partisipatif masyarakat terhadap implementasi program nasional pemberdayaan masyarakat (PNPM)-Mandiri. Jurnal Administrasi Bisnis. [Internet]. [diunduh tanggal 10 Oktober 2013]. 8 (2). Dapat diunduh dari:http://repository.upnyk.ac.id

Yulianti Y. 2012. Analisis partisipasi masyarakat dalam pelaksanaan program nasional pemberdayaan masyarakat (PNPM)-Mandiri Perkotaan di Kota Solok. Jurnal Penelitian. [Internet]. [diunduh tanggal 10 Oktober 2013]. Dapat diunduh dari:http://pasca.unand.ac.id 